\title{
Consequences Of User Experience in A Gamified E- Commerce Platform
}

\author{
Tamana Mominzada \\ Universiti Teknologi Malaysia \\ tamanamominzada@gmail.com \\ Mohd Zaidi Abd Rozan \\ Universiti Teknologi Malaysia \\ mdzaidi@utm.my \\ Najim Ahmad Aziz \\ Kabul University \\ najimaziz@ku.edu.af
}

\begin{abstract}
User experience is essential to any gamified domain, which indicates how a person feels when interacting with the system and it produces some definite consequences. In ecommerce, gamification is increasingly applied as a design strategy while improving various behavioral outcomes. This study explores the consequences of user experience and its role in a gamified e-commerce platform. Hence, a conceptual model of user experience in a gamified e-commerce platform is proposed. The Model aims at finding the effects of gamification on user experience and the consequences that arise. It was statistically tested and validated through a quantitative research approach. An online survey questionnaire acted as the main instrument for data collection and subsequently, the PLS-SEM method was utilized for analyses. The results indicated that in ecommerce, gamification affects user experience positively. This gamified user experience creates satisfied users and enhances their purchasing attitude. Users thus developed a love for a particular brand and become loyal customers of the products. They will also contribute to business growth by spreading positive word of mouth. Finally, the intention of users to engage with a platform is also improved.
\end{abstract}

Keywords: Gamification, E-Commerce, User Experience, Consequences

\section{INTRODUCTION}

E-commerce is defined as sharing business information, keeping business relationships, and conducting business transactions via the internet [1]. E-commerce has different types, among which $\mathrm{B} 2 \mathrm{C}$ is mainly referred to as online shopping. The growth of the 
internet has impacted the online shopping industry. Online shopping grew significantly, as now consumers prefer to buy online compared to offline [2].

Recently, e-commerce platforms employed several methods to attract user's attention. Some reasonably well-known methods are product promotion within diverse social media applications with free shipping \& delivery services. Another method that has created attention is the implementation of gamification features in e-commerce platforms [3]. Increasing user participation or users' behavior transformation, engaging them in the contexts, and improving their experience are the key goals when applying gamification in e-commerce [4].

Gamification is the application of typical game playing elements such as points, scoring, competition with others, rules of play to many other activities. It is typically done as an online marketing technique to encourage engagement with a product or service [5]. Leveraging the elements commonly found in games to make a customer happy, motivated, or attached to a product or service is the objective of gamification [3].

In recent years, user experience is a topic with great interest from both researchers and practitioners. It is viewed as a phenomenon containing all the elements that affect the user's interaction and experience while using a product or a system [6]. User experience is a growing field of research in many contexts. Researchers from different fields have discussed it together with its related factors that potentially affect the user interaction with a system or product.

User experience has become essential for the success of online business activities. Now, it is not sufficient only to think about price and quality, businesses should also think about the construction of an environment where users would enjoy, have fun, can chitchat about, and even win missions with others [5]. This improvement to the user's experience could be achieved by applying game elements in non-game contexts [7].

Recently Hsu and Chen [8] evaluated the improvement of user experience in a gamified context of waste management. The mediation role of user experience and its antecedents \& consequences were explored. It was found that gamification positively affects user experience which in turn can influence perceived value, perceived benefits, and brand equity. Furthermore, Fitz-Walter, et al. [9] investigated the effects of game elements on user experience, motivation, and behavior of a person learning to drive a vehicle. To address the issue of inexperienced drivers, they have adopted a gamified logbook application. As a result, the enjoyment and motivation of participants are positively influenced and most critically, the game elements did not have any adverse effect on the user experience. Looking at another context, user experience was directly affected by gamification features in a gamified recycling website. All the explanations have shown that user experience influences the attitude and intention to use of users [10].

E-commerce is increasingly gamified to make online shopping fun for customers through rewarding them for participation and encouraging them to continue interacting 
with a particular platform [4]. E-commerce platforms want to provide a more enjoyable environment for users, fulfilling their needs, and keeping them loyal to a brand or product. With many online shopping platforms in existence, if the user does not feel good with one, with less hesitation they may switch or leave. Thus, user experience plays a vital role in any e-commerce platform. Meder, et al. [4] studied the positive effects of gamification and found that users could be engaged and motivated with rewards. Moreover, a user will interact more actively if rewards are converted into a utilizable method of exchange or currency that the user deems as tangible.

Thereupon, gamification affects user experience, leading to inevitable results in different contexts such as waste management, operating a vehicle, recycling, marketing, and more. However, very few studies evaluated the consequences of user experience in a gamified e-commerce platform. The effects of gamification on users' motivation, satisfaction, and engagement in the e-commerce context are addressed extensively compared to user experience [6], which is less focused. This phenomenon is well researched in other contexts rather than e-commerce [8-11]. User experience, which is a critical determining factor for e-commerce customer retention, has become the missing component. Thus, this study investigates the consequences of user experience and its role in a gamified e-commerce platform.

\section{LITERATURE REVIEW}

This study evaluates user experience in a gamified e-commerce platform [12, 13]. To do so, the constructs and relationships between them or the hypotheses should be well defined. To explore the effects of gamification features on user experience, the existing body of literature serves as a rich foundation and it enables the development of model constructs and the definition of research hypotheses. A gamified user experience [8-10], in turn, affects user's satisfaction [11], brand love [11], brand loyalty [8, 11], attitude [10], intention to use [10], and positive word of mouth [10]. In the following sections, more discussion on the specific components related to the hypotheses is elaborated.

\subsection{Gamification}

The word gamification came to the literature in the early 2000s. Then, it became out of focus for a decade. By 2010, it regained popularity, and researchers from different contexts focused on it [14]. The relocation of game design elements to a non-gaming platform assembles the main idea of how gamification works. Video games are the source to be referred to comprehend where the source of the motivation appeared. The idea was to bind people into other contexts as they were earlier bounded to video games [5].

Deterding, et al. [5] argue that gamification is an online marketing technique to encourage engagement with a product or service. In this way, gamification applies the typical game playing (points, scoring, competition with others, rules of play, etc.) onto other activity areas. As Yudhoatmojo and Ramadana [3] described, the objective is to 
make the customer happy, motivated, or attached to the product or service being used; by directing elements commonly found in games. Meanwhile, Bakker and Demerouti [15] define gamification as an application of mechanics from gaming to none game activities to change people's behavior. Furthermore, Hsu and Chen [11] argue that gamification is the process of integrating game dynamics (and perhaps, new game mechanics) into a website, business services, online community, or marketing campaign to drive participation and engagement in the business context.

Users could be supported and inspired to accomplish a particular task using gamification. Gamification can realize the goal of making a specific activity more engaging for users [16]. This situation is narrated as a playful experience for the participants of a particular activity.

\subsection{E-Commerce}

According to Bredzel-Skowera and Turek [17], e-commerce is defined as electronic commerce, which is buying and selling goods and products over the internet. The improvement of technology has affected different parts of the current era, including the business world. As an instance, the internet's growth is a driving factor of e-commerce development [18].

Many benefits emerge from online shopping compared to brick-and-mortar. Sellers realize a significant cost saving enabling them to lower the price. Furthermore, a seller can create a purchasing experience that perfectly meets consumers' needs [19]. In an ecommerce platform, consumers can access various providers or sellers, thus sellers are constantly trying to retain their consumers and make them loyal [20]. The issue of customer service is more critical in e-commerce as sellers and consumers do not meet face-to-face. According to Liao, et al. [21] in such platforms, a website is the only interface between retailers and consumers. This is the critical point that establishes the strength of the connection between retailers and consumers. In short, the website's elements can influence the user's perceptions and their decision to switch or leave.

For additional advantages, e-commerce platforms attract the user's attention by incorporating game features [3]. Meder, et al. [4] reveals the basic principle behind the gamification of the e-commerce context. It is to make shopping enjoyable, rewarding, and to encourage interaction with a particular brand.

In addition to clothing, style, and electronics, it is becoming essential to influence people's food selection and persuade them towards good choices. Mostly unhealthy diets end up in severe health problems such as obesity and many other non-contagious metabolic diseases. Adaji and Vassileva [13] have proposed a framework for implementing some game elements and strategies to promote healthier food choices at the sale point in e-commerce. 


\subsection{User Experience}

User experience is a gift received only after using a product or service [22]. It can include different aspects of a person's perception like utility, ease of use, and competence. User experience is dependent on what user or consumer is expecting and what they can receive while interacting with a firm or organization [23]. And it was argued that value creation is not all about selling; it is also about giving people an excellent experience in every moment of their interaction with the firm or organization. Hsu and Chen [11] adds the inclusion of user's emotions, beliefs, preferences, and responses during and after using a particular system or product within user experience.

\subsection{User Satisfaction}

Hsu and Chen [11] argue that satisfaction is one of the core marketing theories, being the key objective of the marketing strategies for almost 60 years. Oliver [24] believes that satisfaction is the judgments and affective reactions during the consumption of any product or service. User satisfaction is a cognitive and emotional evaluation of a customer's experience with a service or product [25]. Customer or user satisfaction is a metric used to quantify the degree to which a customer is happy with a product or service [26].

\subsection{Brand Love}

Brand love is the degree of attachment of a satisfied consumer with a particular brand or trade name [27]. According to Bagozzi, et al. [28], brand love happens from a customer's long-term relationship with a brand. Based on Ahuvia [29], its symptoms include the passion for a brand, attachment to a brand, positive valuation of the brand, and positive emotion towards a specific brand. Overall, when customers love a brand, it indicates that what they are expecting is at par with the received product or service.

\subsection{Brand Loyalty}

Brand loyalty is defined by Oliver [25] as a deep-held commitment to repurchase or preference over a product or service in the future. Chaudhuri and Holbrook [30] and Van den Brink, et al. [31] perceive it as a repetitive purchase from the same brand over other brands.

\subsection{User Attitude}

A user's attitude towards any product or service is initiated from their beliefs about it [32]. These beliefs might be arising from the user experience. If a user perceives it positively, it affects the attitude of the user accordingly. Fishbein and Ajzen [33] believe that user attitude is a learned predisposition of human beings that guides their reaction to an idea or opinion. It becomes clear that user attitude has direct consequences towards a product or service. 


\subsection{Positive Word of Mouth}

Word of mouth (WoM) delegates important Information between consumers of a product or service [34]. It influences the decision of other listening consumers on whether or not to use a product or service. Word of mouth is the degree to which a consumer talks or communicate about a brand to others, which could be positive or negative. East, et al. [35] argue that positive WoM encourages brand choice, and negative WoM does the reverse.

\subsection{Intention to Use}

Intention to use is the level of people's willingness to interact with a product or service. Salam, et al. [36] have evaluated the enthusiasm of users to browse a website and seek Information or perform commercial transactions. For example, consumers who have had a favorable experience of using specific website, are likely to develop favorable attitudes toward the company, along with intentions to visit its Web site again.

\section{PROPOSED MODEL and HYPOTHESES}

The proposed research model as shown in Figure 1 is generated from the literature review performed. The model helps to comprehend the big picture of this study. The goal is to investigate the effects of gamification features on user experience and identify its potential consequences in a gamified e-commerce platform. This section discusses the detailed hypotheses and related supporting literature.

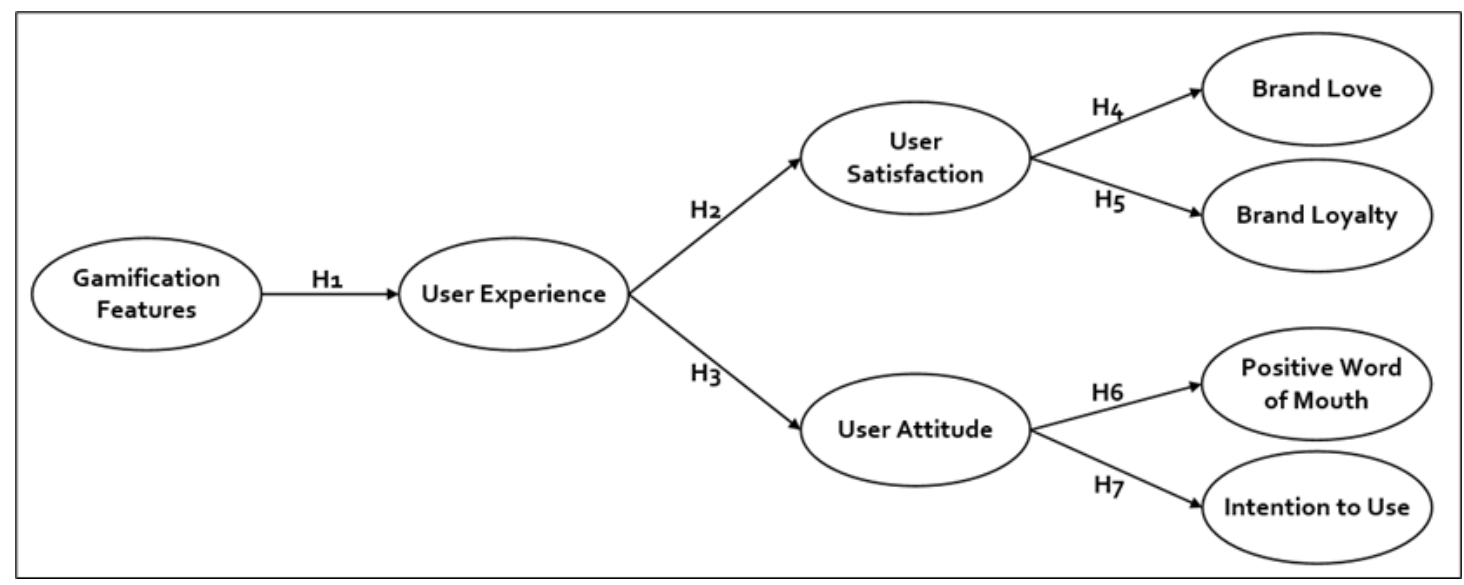

Figure1. Proposed Model

User experience is a set of interactions between a customer and a product, an organization, or a website, which provokes a reaction. According to Sheng and Teo [23], value creation is not only about selling something. It is also enabling the users or customers to live all the moments of the relationship with a company in an excellent way and have a memorable experience even beyond their expectations.

Gamification adds a bit of fun to a context besides motivating users, engaging them further, and improving their experience [14]. Game features are implemented in various 
contexts to realize the benefits of gamification. H1 is developed with the empirical evidence on the positive effects of gamification on user experience $[8,10,11]$. H1: Gamification features will positively influence user experience in an e-commerce platform.

If the user has a good experience, they become satisfied with a product or service [10]. Badran and Al-Haddad [26] have confirmed that user experience has a positive impact on user satisfaction in e-commerce. Moreover, the result of satisfaction affecting brand loyalty is a repurchase of the same product or service [37]. Thus, the following hypothesis is developed. H2: User experience will positively affect user satisfaction in a gamified e-commerce platform.

If the interaction with a product or service is perceived as positive, it will be a good user experience. Sanchez-Franco [38] proved the influence of user experience on the attitude of a user towards websites and brands. As well, in playing mobile-phone-based games such a positive effect is observed [39]. Moreover, Thongmak [40] predicted greater purchasing frequency and buying quantity due to a positive user attitude. Thus, the following hypothesis is developed. H3: User experience will positively influence user attitude.

A positive and emotional brand experience likely ends up with brand love [41]. A user's brand love is likely to be increased when the degree of satisfaction is higher [10, 42]. Therefore, the following hypothesis is developed. H4: User satisfaction will positively influence brand love.

According to Carroll and Ahuvia [27] and Bagozzi, et al. [28], satisfied customers tend to be more loyal to a brand. Aro, et al. [43] proved the positive impact of customer satisfaction on brand loyalty. On the other hand, Christodoulides and Michaelidou [44] found that user satisfaction is the antecedence of loyalty in the shopping context. Thus, the following hypothesis is developed. H5: User satisfaction will positively influence brand loyalty.

There is a close link between user attitude and positive word of mouth $[45,46]$. With a positive attitude, users can talk about a product or service with others positively. Hsu, et al. [10] found that user attitude has a positive effect on user's word of mouth. Thus, the following hypothesis is developed. H6: User attitude will positively influence positive word of mouth.

User attitude has a positive effect on the user's intention to use [10]. With a positive attitude, users will try using the product or service frequently. Hamari and Koivisto [47] found that in a gamified context, attitude leads the users to continue using the gamified service. Thus, the following hypothesis is developed. H7: User attitude will positively influence the intention to use. 


\section{RESEARCH METHODOLOGY}

\subsection{Platform Selection, Sample, and Data Collection}

Deciding on a gamified e-Commerce platform for investigating the consequences of user experience is critical for this study. Here, the reasons why the platform is chosen are explained.

Lazada was found in 2011 and is the most popular online marketplace in Malaysia and the Southeast Asia region. It has around 31.29 million monthly visitors offering a combination of retail and marketplace models. Lazada platform loads faster compared to other e-commerce platforms [48]. It is more organized, and product pages are more detailed, and it is easy to read the about product descriptions with more relevant images.

Lazada has incorporated the gamification features on its platform as currently, it is a trend in e-commerce. To decide a purchase, customers could refer to the reviews \& ratings of products [49]. A progress bar is where users can track their orders, from placing an order to the final delivery. Tangible (cash redemption) or intangible (coin redemption) rewards are offered in terms of Laz Reward. Connection to social networks, social invitation, and sections for providing feedback are amongst the game features found in Lazada. The gamification features mentioned above are just a fraction of them.

The implemented gamification features in Lazada were identified using the Octalysis framework. The Octalysis framework was developed by Chou [50] and is composed of eight core drives summarized in Table 1. Each drive illustrates motivations that a user feels while playing a game and contains several game features or elements. With a complete implementation of the mentioned specifications, Lazada is selected as the target platform for this study.

Table 1. The Octalysis Core Drives [50], Their Game Features \& the Applied Features in Lazada Platform.

\begin{tabular}{|c|c|c|c|}
\hline \# & Octalysis Core Drives & $\begin{array}{l}\text { Game Features in Each } \\
\text { Drive }\end{array}$ & $\begin{array}{l}\text { Implemented } \\
\text { features in Lazada }\end{array}$ \\
\hline 1 & Epic Meaning \& Calling & $\begin{array}{l}\text { Narrative, } \\
\text { Hero, etc. }\end{array}$ & \\
\hline 2 & $\begin{array}{l}\text { Development \& } \\
\text { Accomplishment }\end{array}$ & $\begin{array}{l}\text { Points, Badges, Fixed } \\
\text { action, Rewards, Leader } \\
\text { boards, Progress bar, etc. }\end{array}$ & $\begin{array}{l}\text { Points, Badges, } \\
\text { Rewards, Progress } \\
\text { bar, Leader boards. }\end{array}$ \\
\hline 3 & $\begin{array}{c}\text { Empowerment of } \\
\text { Creativity \& Feedback }\end{array}$ & $\begin{array}{l}\text { Milestone, Unlock, } \\
\text { Instant Feedback, etc. }\end{array}$ & Feedback. \\
\hline 4 & Ownership \& Possession & $\begin{array}{l}\text { Virtual Goods, Protection, } \\
\text { Monitoring, etc. }\end{array}$ & $\begin{array}{l}\text { Monitoring, Virtual } \\
\text { Goods. }\end{array}$ \\
\hline
\end{tabular}


Table 1. The Octalysis Core Drives [50], Their Game Features \& the Applied Features in Lazada Platform.

\begin{tabular}{llll}
\hline \# & $\begin{array}{l}\text { Octalysis Core } \\
\text { Drives }\end{array}$ & Game Features in Each Drive & $\begin{array}{l}\text { Implemented } \\
\text { features in } \\
\text { Lazada }\end{array}$ \\
\hline \multirow{2}{*}{$\begin{array}{l}\text { Social Influences \& } \\
\text { Relatedness }\end{array}$} & $\begin{array}{l}\text { Water Cooler, Group Quest, } \\
\text { Social Inviting, Social Network, } \\
\text { etc. }\end{array}$ & $\begin{array}{l}\text { Social Inviting, } \\
\text { Social Network. }\end{array}$ \\
\hline 6 & Scarcity \& Impatience & Dangling, Prize Pacing, etc. & \\
\hline & Unpredictability \& & Mini Quests, Visual & \\
& Curiosity & Storytelling, Random Rewards, & Random Rewards. \\
& & etc. & \\
\hline 8 & Loss \& Avoidance & Weep Tune, Progress Loss, etc. & \\
\hline
\end{tabular}

To pursue data collection, a web-based questionnaire survey approach is used, considering its efficient nature of collecting a large amount of information from a large population sample [51]. While using PLS-SEM, a sample of 100 is acceptable [51]. In this study, a more systematic and authentic method for calculating the sample size was adopted. The proposed model has a maximum of 3 arrows pointing into a single construct. It means each construct is being measured by a maximum of 3 items. As recommended by [51], a sample size of 124 is sufficient. This number is calculated based on a $5 \%$ probability of errors, $80 \%$ statistical power, and a minimum requirement of $10 \%$ explained variance. In line with the above recommendation and assumptions together with taking into account the chances of missing data, a minimum sample size of 140 was planned [52].

Once the questionnaire was developed and hosted online, a link to its address was distributed to almost 800 recipients through email, social media, and face-to-face notifications. The participants were required to answer the questionnaire based on their experience of using Lazada. At the end of the data collection phase, a sum of 182 individuals have participated in the survey. All of the questions were answered by the respondents as this was the default setting for the online survey, thus, there were no incomplete submissions. However, some invalid and duplicate samples were identified after a thorough analysis. Finally, only 150 responses were identified as usable for analysis.

\subsection{Instrument Development}

To develop a reliable and valid instrument, it is important to adopt a standard and accepted process [53]. The core criteria to measure are content validity, construct validity \& reliability [54]. 
The constructs in this study were measured using multiple items listed in Table 2. The items are evaluated against a seven-point Likert scale from strongly disagree to strongly agree $[8,10,11]$.

Table 2. Measurement Items for the Constructs of the Proposed Model

Constructs Items

Reference

1. I feel the Lazada application is cleverly designed.

[8]

2. Purchasing in Lazada and obtaining rewards is fun.

Gamification 3. Lazada doesn't just sell products or services - it

Features entertains me.

4. I have read feedbacks written by other users of Lazada.

1. Lazada tries to excite my senses.

User 2. Lazada causes me to think creatively.

Experience 3. Lazada tries to make me think about my lifestyle.

4. The shopping experience in Lazada was truly a joy.

1. I could find the items that I want to buy in Lazada.

2. I enjoyed shopping in Lazada with gamified

User satisfaction features.

3. Lazada provided me with a good shopping experience.

I can sort out my feelings using Lazada.

2. I can know my true feelings while searching in

User attitude Lazada.

3. I can get over my complaints or conflicts while using Lazada.

1. Lazada is a wonderful shopping environment.

Brand Love 2. Lazada is totally awesome.

3. I am very attached to Lazada.

1. Lazada is the only online shopping application that I buy from.

Brand

2. If Lazada is out of the items that I want to buy, I will postpone buying.

3. I try to use Lazada whenever I need to do shopping.

1. I have recommended shopping with Lazada to lots

Positive of people.

Word of

Mouth

2. I try to spread good remarks about Lazada.

3. The products/services I purchased from the Lazada were good buys. 
Table 2. Measurement Items for the Constructs of the Proposed Model

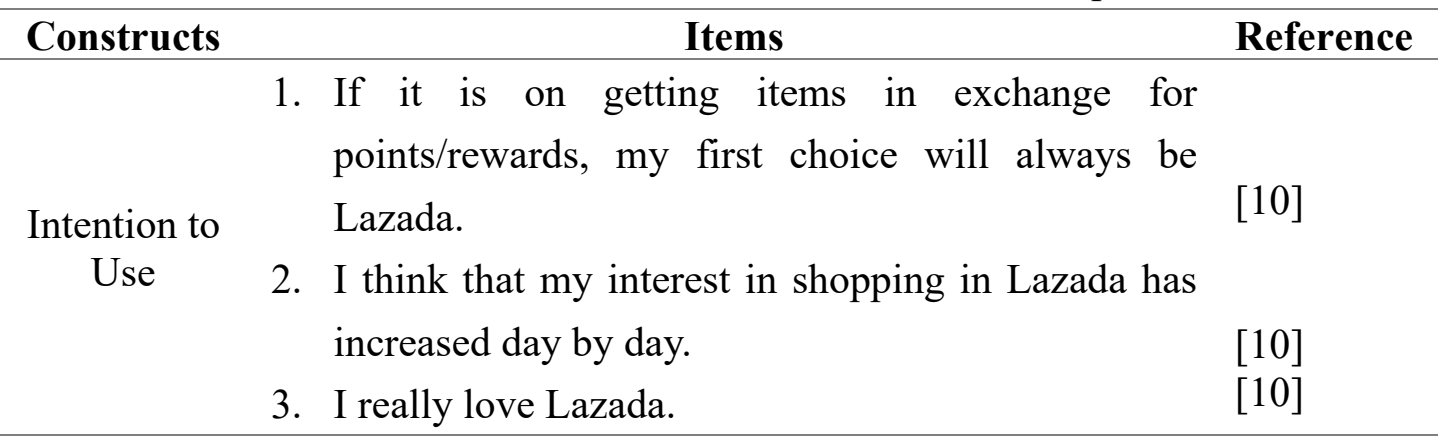

A two-step process was considered to assess the content and construct validity. First, a preliminary version of the instrument was reviewed by two academic experts in the fields of e-commerce and gamification. With their suggestion, minor improvements and modifications were applied to ensure the content validity of the questionnaire. Subsequently, to ensure the item's validity, the instrument was reviewed by an English language specialist. It helped the respondent to understand the questions in the easiest, comprehensive, and straightforward words.

A pilot study was conducted to test the reliability of the instrument. According to Hill [61], 10 to 30 participants are adequate for the pilot studies, while [62] mentioned that as low as 12 participants are enough for the pilot studies. The questionnaire was sent to 20 potential respondents, out of which only 13 responses were verified. The results of the pilot test were used to verify that the questionnaire has satisfactory reliability and validity.

\section{DATA ANALYSIS AND RESULTS}

Demographic analysis was performed to understand the overall profile of the respondents. Table 3 presents the gender, age group, and education level of the respondents.

Table 3. Demographic Information of the Respondents $(n=150)$

\begin{tabular}{lll}
\hline Gender & & \\
\hline Male & 101 & $(67.33 \%)$ \\
\hline Female & 46 & $(30.67 \%)$ \\
\hline Missing* & 3 & $(2 \%)$
\end{tabular}

\begin{tabular}{lll}
\multicolumn{2}{l}{ Age Group } \\
\hline$<=20$ & 14 & $(9.33 \%)$ \\
\hline $21-30$ & 80 & $(53.33 \%)$ \\
\hline $31-40$ & 36 & $(24 \%)$ \\
\hline $41-50$ & 16 & $(10.67 \%)$ \\
\hline$>50$ & 3 & $(2 \%)$ \\
\hline Missing* & 1 & $(0.67 \%)$
\end{tabular}

\section{Education Level}

\begin{tabular}{lll}
$\begin{array}{l}\text { High School or } \\
\text { Below }\end{array}$ & 5 & $(3.33 \%)$ \\
\hline Bachelor's Degree & 23 & $(15.33 \%)$ \\
\hline Postgraduate Degree & 119 & $(79.33 \%)$ \\
\hline Missing* & 3 & $(2 \%)$ \\
\hline
\end{tabular}


PLS-SEM is used to analyze the instrument validity and reliability via Smart PLS 3.0 software. PLS is more suitable for cases in which the researcher aims to predict the constructs and investigate their relationships and with a small sample size [51].

\subsection{Measurement Model Analysis}

The first step to have a valid model is to ensure that each particular construct is measured correctly. This study evaluated construct validity and reliability in several ways.

First, the indicator reliability was assessed via outer loadings. Outer loadings evaluate the indicator/item reliability, and it measures how much a particular indicator can measure its related construct. Hair Jr, et al. [63] states 0.708 as a recommended value for outer loadings. As indicated in Table 4, all items' outer loadings are higher than the recommended value, except gamification features' fourth item, the GF04.

Table 4. Outer Loadings Values for Measurement Items

\begin{tabular}{|c|c|c|c|c|c|}
\hline Constructs & Indicators & $\begin{array}{c}\text { Outer } \\
\text { Loadings }\end{array}$ & Constructs & Indicators & $\begin{array}{c}\text { Outer } \\
\text { Loadings }\end{array}$ \\
\hline \multirow{4}{*}{$\begin{array}{l}\text { Gamification } \\
\text { Features }\end{array}$} & GF01 & 0.709 & \multirow{3}{*}{$\begin{array}{l}\text { Brand } \\
\text { Love }\end{array}$} & BL01 & 0.918 \\
\hline & GF02 & 0.847 & & BL02 & 0.931 \\
\hline & GF03 & 0.749 & & BL03 & 0.850 \\
\hline & GF04 & 0.428 & \multirow{3}{*}{$\begin{array}{l}\text { Brand } \\
\text { Loyalty }\end{array}$} & BLY01 & 0.859 \\
\hline \multirow{4}{*}{$\begin{array}{l}\text { User } \\
\text { Experience }\end{array}$} & UX01 & 0.851 & & BLY02 & 0.810 \\
\hline & UX02 & 0.834 & & BLY03 & 0.852 \\
\hline & UX03 & 0.817 & \multirow{3}{*}{$\begin{array}{l}\text { Positive } \\
\text { Word of } \\
\text { Mouth }\end{array}$} & POWM01 & 0.906 \\
\hline & UX04 & 0.763 & & POWM02 & 0.918 \\
\hline \multirow{3}{*}{$\begin{array}{l}\text { User } \\
\text { Satisfaction }\end{array}$} & US01 & 0.724 & & POWM03 & 0.803 \\
\hline & US02 & 0.810 & \multirow{3}{*}{$\begin{array}{l}\text { Intention to } \\
\text { Use }\end{array}$} & ITU01 & 0.885 \\
\hline & US03 & 0.870 & & ITU02 & 0.921 \\
\hline \multirow{3}{*}{$\begin{array}{l}\text { User } \\
\text { Attitude }\end{array}$} & UA01 & 0.921 & & ITU03 & 0.900 \\
\hline & UA02 & 0.914 & & & \\
\hline & UA03 & 0.849 & & & \\
\hline
\end{tabular}

Second, internal consistency reliability was evaluated via composite reliability. The accepted threshold for composite reliability is a value above 0.70 [63]. Convergent validity is assessed as well. It could be measured by the average variance extracted (AVE), and the recommended threshold for AVE is a value above 0.50. As indicated in Table 5, the returned values of composite reliability and AVE for all constructs are acceptable. 
Table 5. Results of Composite Reliability and AVE

\begin{tabular}{|c|c|c|c|c|c|}
\hline Constructs & $\begin{array}{l}\text { Composite } \\
\text { Reliability }\end{array}$ & AVE & Constructs & $\begin{array}{l}\text { Composite } \\
\text { Reliability }\end{array}$ & AVE \\
\hline $\begin{array}{l}\text { Gamification } \\
\text { Features }\end{array}$ & 0.830 & 0.620 & Brand Loyalty & 0.878 & 0.706 \\
\hline $\begin{array}{l}\text { User } \\
\text { Experience }\end{array}$ & 0.889 & 0.668 & User Attitude & 0.923 & 0.801 \\
\hline $\begin{array}{l}\text { User } \\
\text { Satisfaction }\end{array}$ & 0.845 & 0.646 & $\begin{array}{l}\text { Positive Word } \\
\text { of Mouth }\end{array}$ & 0.909 & 0.769 \\
\hline Brand Love & 0.928 & 0.811 & $\begin{array}{l}\text { Intention To } \\
\text { Use }\end{array}$ & 0.929 & 0.813 \\
\hline
\end{tabular}

The last assessment for the measurement model was discriminant validity. It shows whether a construct is unique and other constructs in the model do not present the specific phenomena. It is measured with Fornell-Larker Criterion and cross-loading. However, with the long constructs, abbreviations are used as shown in Table 6. Table 7 and Table 8 contain the measured values for discriminant validity.

Table 6. Abbreviations \& Complete Forms of Construct Names

\begin{tabular}{llll}
\hline Abbreviation & Complete Form & Abbreviation & Complete Form \\
\hline GF & Gamification Features & PWOM & Positive Word of Mouth \\
\hline UX & User Experience & BL & Brand Love \\
\hline US & User Satisfaction & BLY & Brand Loyalty \\
\hline UA & User Attitude & ITU & Intention to Use
\end{tabular}

Table 7. Fornell-Larcker Criterion

\begin{tabular}{lllllllll}
\hline & BL & BLY & GF & ITU & PWOM & UA & US & UX \\
\hline BL & 0.900 & & & & & & & \\
\hline BLY & 0.599 & 0.840 & & & & & & \\
\hline GF & 0.596 & 0.452 & 0.788 & & & & & \\
\hline ITU & 0.685 & 0.729 & 0.576 & 0.902 & & & & \\
\hline PWOM & 0.746 & 0.667 & 0.483 & 0.812 & 0.877 & & & \\
\hline UA & 0.656 & 0.514 & 0.482 & 0.621 & 0.612 & 0.895 & & \\
\hline US & 0.747 & 0.511 & 0.544 & 0.590 & 0.634 & 0.524 & 0.804 & \\
\hline UX & 0.722 & 0.500 & 0.693 & 0.656 & 0.628 & 0.670 & 0.629 & 0.817 \\
\hline & & & & & & & &
\end{tabular}


Table 8. Measurement Items of the Constructs

\begin{tabular}{|c|c|c|c|c|c|c|c|c|}
\hline & BL & BLY & GF & ITU & PWOM & UA & US & UX \\
\hline BL01 & 018 & 0.476 & 0.510 & 0.573 & 0.700 & 0.545 & 0.728 & 0.619 \\
\hline BL02 & 3 & 0 & 5 & 0.611 & 4 & 562 & 0.667 & 0.666 \\
\hline BL03 & 0.850 & 0 & 0.538 & 0.677 & 0 . & 676 & 0.616 & 0.670 \\
\hline BLY01 & 0.449 & 0.859 & 0.299 & 0.518 & 0.464 & .371 & 0.392 & 0.319 \\
\hline BLY02 & 0.377 & 0.810 & 0.308 & 0.559 & 0.497 & 350 & 0.386 & 0.369 \\
\hline BLY03 & 0.647 & 0.852 & 0.500 & 0.730 & 0.687 & .546 & 0.494 & 0.540 \\
\hline GF01 & 0.493 & 0.360 & 0.712 & 0.376 & 0.388 & 0.260 & 0.494 & 0.439 \\
\hline GF02 & 0.531 & 0.351 & 0.862 & 0.547 & 0.476 & 0.409 & 0.499 & 0.602 \\
\hline GF03 & 0.396 & 0.364 & 0.782 & 0.424 & 0.283 & 0.445 & 0.314 & 0.579 \\
\hline ITU01 & 0.543 & 0.701 & 0.487 & 0.885 & 0.647 & 0.516 & 0.509 & 0.529 \\
\hline ITU02 & 0.629 & 0.629 & 0.500 & 0.921 & 0.746 & 0.610 & 0.496 & 0.599 \\
\hline ITU03 & 0.677 & 0.649 & 0.575 & 0.900 & 0.799 & 0.549 & 0.596 & 0.644 \\
\hline PWOMO & 0.640 & 0.59 & 0.421 & 0.786 & 0.906 & 0.551 & 0.551 & 0.557 \\
\hline PWOM02 & 0.689 & 0.638 & 0.461 & 0.773 & 0.9 & 0.579 & 0.614 & 0.585 \\
\hline PWOM03 & 0.636 & 0.519 & 0.386 & 0.559 & 0.803 & 0.473 & 0.499 & 0.509 \\
\hline UA01 & 0.608 & 0.546 & 0.492 & 0.610 & 0 . & 0 & 0.469 & 0.622 \\
\hline UA02 & 0.621 & 0.481 & 0.402 & 0.565 & 0.56 & 0 . & 0.506 & 0.641 \\
\hline UA03 & 0.526 & 0.336 & 0.395 & 0.485 & 0.494 & 0.849 & 0.429 & 0.529 \\
\hline US01 & 0.458 & 0.337 & 0.283 & 0.327 & 0.427 & 0.249 & 0.724 & 0.402 \\
\hline US02 & 0.590 & 0.392 & 0.531 & 0.535 & 0.495 & 0.565 & 0.810 & 0.574 \\
\hline US03 & 0.721 & 0.487 & 0.469 & 0.531 & 0.591 & 0.420 & 0.870 & 0.527 \\
\hline UX01 & 0.588 & 0.428 & 0.620 & 0.581 & 0.580 & 0.524 & 0.499 & 0.851 \\
\hline UX02 & 0.507 & 0.370 & 0.548 & 0.488 & 0.400 & 0.575 & 0.461 & 0.835 \\
\hline UX03 & 0.494 & 0.332 & 0.533 & 0.461 & 0.400 & 0.555 & 0.379 & 0.819 \\
\hline UX04 & 0.741 & 0.485 & 0.557 & 0.596 & 0.644 & 0.532 & 0.685 & 0.761 \\
\hline
\end{tabular}

It is confirmed that all the items and constructs are unique, referring to the results presented in Table 7 and Table 8 . In conclusion, the measurement model is successfully evaluated, having adequate statistics of reliability and validity.

\subsection{Structural Model Analysis}

The Structural Model evaluates the relationship between the constructs of a model. It includes several steps to be considered. First, collinearity checks were assessed via the 
variance inflation factor for both constructs and items. Collinearity happens when items are highly correlated. Items and constructs need to be checked to determine if any of them should be deleted or merged. Table 9 is the result of the collinearity check for the items.

Table 9. Outer VIF Values for Measurement Items in the Model

\begin{tabular}{|c|c|c|c|c|c|}
\hline Indicators & VIF & Indicators & VIF & Indicators & VIF \\
\hline GF01 & 1.345 & UX01 & 2.068 & US01 & 1.350 \\
\hline GF02 & 1.616 & UX02 & 2.109 & US02 & 1.447 \\
\hline GF03 & 1.322 & UX03 & 2.068 & US03 & 1.634 \\
\hline BL01 & 3.071 & UX04 & 1.461 & UA01 & 2.897 \\
\hline BL02 & 3.528 & BLY01 & 1.951 & UA02 & 2.791 \\
\hline BL03 & 1.983 & BLY02 & 1.671 & UA03 & 1.962 \\
\hline PWOM01 & 2.763 & BLY03 & 1.585 & ITU01 & 2.361 \\
\hline PWOM02 & 2.873 & & & ITU02 & 2.754 \\
\hline PWOM03 & 1.618 & & & ITU03 & 2.529 \\
\hline
\end{tabular}

Table 10. Inner VIF Values for Constructs in the Model

\begin{tabular}{c|c|c|c|c|c|c|c|c}
\hline BL & BL & BLY & GF & ITU & PWOM & UA & US & UX \\
\hline BLY & & & & & & & & \\
\hline GF & & & & & & & & 1 \\
\hline ITU & & & & & & & & \\
\hline PWOM & & & & & & & & \\
\hline UA & & & & 1 & 1 & & & \\
\hline US & 1 & 1 & & & & & & \\
\hline UX & & & & & & 1 & 1 & \\
\hline
\end{tabular}

The recommended value range for the collinearity issue, suggested by [63], is between 1 - 5. No correlation was found between items and constructs, as presented in Table 9 and Table 10.

The bootstrapping function of Smart-PLS 3.0 was used to assess the path coefficients of the Structural Model. A summary of the bootstrapping results, t-values, and the estimated $\mathrm{p}$-values related to each t-value is presented in Table 11. 
Table 11. Path Coefficients Assessment in the Model

\begin{tabular}{|c|c|c|c|c|c|}
\hline Relationship & $\begin{array}{l}\text { Expected } \\
\text { Sign }\end{array}$ & $\begin{array}{l}\text { Path } \\
\text { Coefficients } \\
(\beta)\end{array}$ & $\begin{array}{l}\text { t } \\
\text { Values }\end{array}$ & $\begin{array}{l}\text { p } \\
\text { Values }\end{array}$ & $\begin{array}{l}\text { Relevant } \\
\text { Hypothesis }\end{array}$ \\
\hline $\mathbf{G F} \rightarrow \mathbf{U X}$ & + & 0.709 & 14.683 & 0 & $\mathrm{H} 1$ is supported \\
\hline $\mathbf{U X} \rightarrow \mathbf{U S}$ & + & 0.629 & 8.981 & 0 & $\mathrm{H} 2$ is supported \\
\hline $\mathbf{U X} \rightarrow \mathbf{U A}$ & + & 0.670 & 16.055 & 0 & $\mathrm{H} 3$ is supported \\
\hline $\mathbf{U S} \rightarrow \mathbf{B L}$ & + & 0.747 & 13.736 & 0 & $\mathrm{H} 4$ is supported \\
\hline $\mathbf{U S} \rightarrow \mathbf{B L Y}$ & + & 0.511 & 8.684 & 0 & H5 is supported \\
\hline $\begin{array}{l}\text { UA } \rightarrow \\
\text { PWOM }\end{array}$ & + & 0.612 & 11.199 & 0 & H6 is supported \\
\hline $\mathbf{U A} \rightarrow \mathbf{I T U}$ & + & 0.621 & 9.724 & 0 & $\mathrm{H} 7$ is supported \\
\hline
\end{tabular}

Path coefficients evaluate the hypothesis relationship between the research model constructs. If the returned p-value ranges from 0.001 to 0.05 , it indicates that the relationship is significant among constructs [63].

Based on the above results, all paths are significant at the level of below 0.05. It is indicated that gamification features have a positive significant effect on user experience $(\beta=0.709$, $p$-value $<0.000)$. In turn, user experience positively affects user satisfaction $(\beta=0.629$, p-value $<0.000)$, and user attitude $(\beta=0.670, p$-value $<0.000)$. Hence supporting $\mathrm{H} 1, \mathrm{H} 2$, and $\mathrm{H} 3$. The $\mathrm{H} 4$, and $\mathrm{H} 5$ were also confirmed as the user satisfaction has its positive effects on brand love and brand loyalty $(\beta=0.747$, p-value $<0.000)$, $(\beta$ $=0.511, \mathrm{p}$-value $<0.000)$. Furthermore, user attitude was also found to influence positive word of mouth and intention to use of users positively $(\beta=0.612$, p-value $<$ $0.000, \beta=0.621$, p-value $<0.000$ ), this resulted confirming the $\mathrm{H} 6$ and H7. As stated above, all proposed hypotheses are supported. To evaluate the explanatory power of the proposed Model, the coefficient of determination $\mathrm{R}^{2}$ is assessed. $\mathrm{R}^{2}$ Values shown in Table 12 range from 0.261 to 0.558 , indicating an adequate level of predictive capability for the Model.

Table 12. The $\mathrm{R}^{2}$ value of the Constructs in the Model

\begin{tabular}{ccc}
\hline Dependent Constructs & R Square & Interpretation \\
\hline Brand Love & 0.558 & Substantial \\
\hline Brand Loyalty & 0.261 & Moderate \\
\hline Intention to Use & 0.386 & Moderate \\
\hline Positive Word of Mouth & 0.374 & Moderate \\
\hline
\end{tabular}


Table 12. The $\mathrm{R}^{2}$ value of the Constructs in the Model

\begin{tabular}{ccc}
\hline Dependent Constructs & R Square & Interpretation \\
\hline User Attitude & 0.449 & Moderate \\
\hline User Satisfaction & 0.396 & Moderate \\
\hline User Experience & 0.481 & Moderate \\
\hline
\end{tabular}

\section{DISCUSSION AND IMPLICATIONS}

Several studies were conducted in the contexts of marketing, resource management, and recycling-related websites regarding gamification $\&$ how it affects the users' experience. However, few studies examined how gamification affects user experience in the e-commerce context, and what will be the consequences.

This study contributes to the scarce studies and comprehensively provides empirical evidence which proves that gamification has a strong effect on user experience in ecommerce. The role of user experience is also confirmed. It is found that user experience plays an essential role in the satisfaction of a user, attitude of a user, brand love, brand loyalty, positive word of mouth, and the intention to use of the users; in an e-commerce platform. Overall, the defined hypotheses of this study have been supported by empirical evidence.

It is confirmed that gamification has significant effects on user experience resulting in specific consequences such as the contexts of waste management [8], marketing [11], and recycling website [10]. The gamified user experience and its consequences as the key determining factors for e-commerce customer retention have become a missing component in the e-commerce context. Thus, on a theoretical level, this study's results serve as empirical evidence for the vital role that user experience plays in an environment where gamification is in place. This study contributes to the literature addressing the role of user experience and its consequences in an e-commerce platform. It also highlighted the significance of user experience in understanding user satisfaction, user attitude, positive word of mouth, intention to use, brand love, and brand loyalty in a gamified e-commerce platform. Furthermore, this study extends the findings of Hsu, et al. [10], who argued that user experience is significantly affecting user's attitudes. In turn, user attitude has it is positive effects on intention to use of a user and positive word of mouth in a gamified context. As indicated by Hsu, et al. [10] when a user has a good experience of using a platform, they will try to use the platform frequently and spread good words about it.

From a managerial perspective, gamification has been applied to different contexts for increasing user's engagement, motivation, and experience. Additionally, gamification is observed as a new way of enhancing users' participation in various activities. The results of this study would assist managers in improving their understanding of the user's perceptions. It could be achieved by leveraging gamification as a tool to increase their user's experience and identify the consequences of gamified user experience in the 
e-commerce context. Businesses can increase their user's brand love, brand loyalty, positive word of mouth, and, most importantly, the intention to use via gamification features.

\section{LIMITATION AND FUTURE WORKS}

With the attempt to contribute to knowledge, this study is certainly not free from limitations. Here, the possible directions for future research are suggested. First, the choice of case study is Lazada, which is a gamified e-commerce platform. Even though justifications were provided in determining Lazada as the case, future studies could enhance the survey to evaluate gamification in different contexts such as travel and tourism, education, e-banking, or e-health. Such studies will help to improve the validity of results on gamification research in vast contexts.

Second, the respondents of this study were based in Malaysia. It means this study was conducted in a specific region where people are using the Lazada platform. Future studies may adopt the same approach, but exploring with another group of samples as well as with the diverse cultural backgrounds increases the richness of the demographic under study.

Third, this study examined the role of user experience and its consequences in a gamified e-commerce platform. Further studies could evaluate the role of the user's motivation and engagement to discover their specific consequences. Finally, although this study has proved some consequences of user experience, future studies could extend the model in this study by exploring and distinguishing other consequences of user experience in a gamified e-commerce platform.

\section{REFERENCES}

[1] Z. Vladimir, "Electronic commerce: structures and issues," International journal of electronic commerce, vol. 1, no. 1, pp. 3-23, 1996.

[2] T. M. Nisar and G. Prabhakar, "What factors determine e-satisfaction and consumer spending in e-commerce retailing?," Journal of retailing and consumer services, vol. 39, pp. 135-144, 2017.

[3] S. B. Yudhoatmojo and R. Ramadana, "Analysis on gamification features usage on Indonesia ecommerce sites using Octalysis Framework," in The 2nd International HCI and UX Conference in Indonesia, Jakarta, Indonesia, 2016, pp. $1-5$.

[4] M. Meder, T. Plumbaum, A. Raczkowski, B. Jain, and S. Albayrak, "Gamification in E-Commerce: Tangible vs. Intangible Rewards," in Proceedings 
of the 22nd International Academic Mindtrek Conference, 2018, pp. 11-19.

[5] S. Deterding, D. Dixon, R. Khaled, and L. Nacke, "From game design elements to gamefulness: defining" gamification"," in Proceedings of the 15th international academic MindTrek conference: Envisioning future media environments, 2011, pp. 9-15.

[6] T. Partala and T. Saari, "Understanding the most influential user experiences in successful and unsuccessful technology adoptions," Computers in Human Behavior, vol. 53, pp. 381-395, 2015.

[7] Y. Yang, Y. Asaad, and Y. Dwivedi, "Examining the impact of gamification on intention of engagement and brand attitude in the marketing context," Computers in Human Behavior, vol. 73, pp. 459-469, 2017.

[8] C.-L. Hsu and M.-C. Chen, "How does gamification improve user experience? An empirical investigation on the antecedences and consequences of user experience and its mediating role," Technological Forecasting and Social Change, vol. 132, pp. 118-129, 2018.

[9] Z. Fitz-Walter, D. Johnson, P. Wyeth, D. Tjondronegoro, and B. Scott-Parker, "Driven to drive? Investigating the effect of gamification on learner driver behavior, perceived motivation and user experience," Computers in Human Behavior, vol. 71, pp. 586-595, 2017.

[10] C.-L. Hsu, Y.-C. Chen, T.-N. Yang, and W.-K. Lin, "Do website features matter in an online gamification context? Focusing on the mediating roles of user experience and attitude," Telematics and Informatics, vol. 34, no. 4, pp. 196-205, 2017.

[11] C.-L. Hsu and M.-C. Chen, "How gamification marketing activities motivate desirable consumer behaviors: Focusing on the role of brand love," Computers in Human Behavior, vol. 88, pp. 121-133, 2018.

[12] S. Hansun, "Gamified e-Commerce A New Paradigm on e-Media Business," Ultimatics: Jurnal Teknik Informatika, vol. 4, no. 2, pp. 28-31, 2012.

[13] I. Adaji and J. Vassileva, "A gamified system for influencing healthy ecommerce shopping habits," in Adjunct Publication of the 25th Conference on User Modeling, Adaptation and Personalization, 2017, pp. 398-401.

[14] L. Sardi, A. Idri, and J. L. Fernández-Alemán, "A systematic review of gamification in e-Health," Journal of biomedical informatics, vol. 71, pp. 31-48, 
2017.

[15] A. B. Bakker and E. Demerouti, "The job demands-resources model: State of the art," Journal of managerial psychology, vol. 22 no. 3, pp. 309-328, 2007.

[16] J. Koivisto and J. Hamari, "Demographic differences in perceived benefits from gamification," Computers in Human Behavior, vol. 35, pp. 179-188, 2014.

[17] K. Bredzel-Skowera and T. Turek, "The prospects of E-commerce in Poland," Procedia Computer Science, vol. 65, pp. 1114-1123, 2015.

[18] P. W. Handayani, I. M. E. Ariantana, and A. Pinem, "How to increase customer repurchase intention in a business-to-customer (B2C)?," " International Journal of Electronic Commerce Studies", vol. 11, no. 1, pp. 13-32, 2020.

[19] M. Warkentin, R. Bapna, and V. Sugumaran, "The role of mass customization in enhancing supply chain relationships in B2C e-commerce markets," J. Electron. Commerce Res., vol. 1, no. 2, pp. 45-52, 2000.

[20] M. Singh, "E-services and their role in B2C e-commerce," Managing Service Quality: An International Journal, vol. 12 no. 6, pp. 434-446, 2002.

[21] C. Liao, P. Palvia, and H.-N. Lin, "The roles of habit and web site quality in ecommerce," International Journal of Information Management, vol. 26, no. 6, pp. 469-483, 2006.

[22] B. J. Pine, J. Pine, and J. H. Gilmore, The experience economy: work is theatre \& every business a stage. Harvard Business Press, 1999.

[23] M. L. Sheng and T. S. H. Teo, "Product attributes and brand equity in the mobile domain: The mediating role of customer experience," International Journal of Information Management, vol. 32, no. 2, pp. 139-146, 2012.

[24] R. L. Oliver, "An investigation of the attribute basis of emotion and related affects in consumption: suggestions for a stage-specific satisfaction framework," $A C R$ North American Advances, vol. 19, pp.237-244, 1992.

[25] R. L. Oliver, "Whence consumer loyalty?," Journal of marketing, vol. 63, no. 4_suppl1, pp. 33-44, 1999.

[26] O. Badran and S. Al-Haddad, "The Impact of Software User Experience on Customer Satisfaction," Journal of Management Information and Decision Sciences, vol. 21, no. 1, pp. 1-20, 2018.

[27] B. A. Carroll and A. C. Ahuvia, "Some antecedents and outcomes of brand love," Marketing Letters, vol. 17, no. 2, pp. 79-89, 2006. 
[28] R. P. Bagozzi, R. Batra, and A. Ahuvia, "Brand love: development and validation of a practical scale," Marketing Letters, vol. 28, no. 1, pp. 1-14, 2017.

[29] A. C. Ahuvia, "The love prototype revisited: A qualitative exploration of contemporary folk psychology," in University of Michigan-Dearborn working paper, 2005.

[30] A. Chaudhuri and M. B. Holbrook, "The chain of effects from brand trust and brand affect to brand performance: the role of brand loyalty," Journal of marketing, vol. 65, no. 2, pp. 81-93, 2001.

[31] D. Van den Brink, G. Odekerken-Schröder, and P. Pauwels, "The effect of strategic and tactical cause-related marketing on consumers' brand loyalty," Journal of Consumer Marketing, vol. 23, no. 1, pp. 15-25, 2006.

[32] G. J. Shepherd and D. J. O'keefe, "Separability of attitudinal and normative influences on behavioral intentions in the Fishbein-Ajzen model," The Journal of Social Psychology, vol. 122, no. 2, pp. 287-288, 1984.

[33] M. Fishbein and I. Ajzen, "Belief, attitude, intention, and behavior: An introduction to theory and research," 1977.

[34] C. W. Yoo, Y. J. Kim, and G. L. Sanders, "The impact of interactivity of electronic word of mouth systems and E-Quality on decision support in the context of the emarketplace," Information \& Management, vol. 52, no. 4, pp. 496-505, 2015.

[35] R. East, K. Hammond, and W. Lomax, "Measuring the impact of positive and negative word of mouth on brand purchase probability," International journal of research in marketing, vol. 25, no. 3, pp. 215-224, 2008.

[36] A. F. Salam, L. Iyer, P. Palvia, and R. Singh, "Trust in e-commerce," Communications of the ACM, vol. 48, no. 2, pp. 72-77, 2005.

[37] G. A. Churchill Jr and C. Surprenant, "An investigation into the determinants of customer satisfaction," Journal of marketing research, vol. 19, no. 4, pp. 491-504, 1982.

[38] M. J. Sanchez-Franco, "Exploring the influence of gender on the web usage via partial least squares," Behaviour \& Information Technology, vol. 25, no. 1, pp. 19-36, 2006.

[39] M.-C. Lee and T.-R. Tsai, "What drives people to continue to play online games? An extension of technology model and theory of planned behavior," Intl. journal of human-computer interaction, vol. 26, no. 6, pp. 601-620, 2010. 
[40] M. Thongmak, "Do we know what contents work for social commerce? A case of customer engagement in Facebook brand pages," "International Journal of Electronic Commerce Studies", vol. 10, no. 2, pp. 141-174, 2019.

[41] S. K. Roy, A. Eshghi, and A. Sarkar, "Antecedents and consequences of brand love," Journal of Brand Management, vol. 20, no. 4, pp. 325-332, 2013.

[42] J. Drennan, C. Bianchi, S. Cacho-Elizondo, S. Louriero, N. Guibert, and W. Proud, "Examining the role of wine brand love on brand loyalty: A multi-country comparison," International Journal of Hospitality Management, vol. 49, pp. 47$55,2015$.

[43] K. Aro, K. Suomi, and S. Saraniemi, "Antecedents and consequences of destination brand love - A case study from Finnish Lapland," Tourism Management, vol. 67, pp. 71-81, 2018.

[44] G. Christodoulides and N. Michaelidou, "Shopping motives as antecedents of esatisfaction and e-loyalty," Journal of Marketing Management, vol. 27, no. 1-2, pp. 181-197, 2010.

[45] A. Baber, R. Thurasamy, M. I. Malik, B. Sadiq, S. Islam, and M. Sajjad, "Online word-of-mouth antecedents, attitude and intention-to-purchase electronic products in Pakistan," Telematics and Informatics, vol. 33, no. 2, pp. 388-400, 2016.

[46] T.-Y. Wu and C. A. Lin, "Predicting the effects of eWOM and online brand messaging: Source trust, bandwagon effect and innovation adoption factors," Telematics and Informatics, vol. 34, no. 2, pp. 470-480, 2017.

[47] J. Hamari and J. Koivisto, "Why do people use gamification services?," International Journal of Information Management, vol. 35, no. 4, pp. 419-431, 2015.

[48] V. Zoleta. (2019, April. 23) "Lazada vs Shopee: Which is the Better Online Shopping Site?" https://www.moneymax.ph/personal-finance/articles/lazada-vsshopee-review.

[49] Y.-k. Chou, "Actionable gamification," Beyond points, badges, and leaderboards, 2015.

[50] Y.-k. Chou, Actionable gamification: Beyond points, badges, and leaderboards. Packt Publishing Ltd, 2019.

[51] M. Sarstedt, C. M. Ringle, D. Smith, R. Reams, and J. F. Hair Jr, "Partial least 
squares structural equation modeling (PLS-SEM): A useful tool for family business researchers," Journal of Family Business Strategy, vol. 5, no. 1, pp. 105$115,2014$.

[52] M. Saunders, P. Lewis, and A. Thornhill, Research methods for business students. Pearson education, 2009.

[53] T. R. Hinkin, "A brief tutorial on the development of measures for use in survey questionnaires," Organizational research methods, vol. 1, no. 1, pp. 104-121, 1998.

[54] D. Gefen, D. Straub, and M.-C. Boudreau, "Structural equation modeling and regression: Guidelines for research practice," Communications of the association for information systems, vol. 4, no. 1, p. 7, 2000.

[55] J. W. Overby and E.-J. Lee, "The effects of utilitarian and hedonic online shopping value on consumer preference and intentions," Journal of Business Research, vol. 59, no. 10, pp. 1160-1166.

[56] A. Bilgihan and M. Bujisic, "The effect of website features in online relationship marketing: A case of online hotel booking," Electronic commerce research and applications, vol. 14, no. 4, pp. 222-232, 2015.

[57] V. M. Roudposhti, M. Nilashi, A. Mardani, D. Streimikiene, S. Samad, and O. Ibrahim, "A new model for customer purchase intention in e-commerce recommendation agents," Journal of International Studies, vol. 11, no. 4, 2018.

[58] S. Taylor and P. A. Todd, "Understanding information technology usage: A test of competing models," Information systems research, vol. 6, no. 2, pp. 144-176, 1995.

[59] D. Li, G. J. Browne, and P. Y. Chau, "An empirical investigation of web site use using a commitment-based model," Decision Sciences, vol. 37, no. 3, pp. 427444, 2006.

[60] J. G. Maxham III and R. G. Netemeyer, "Firms reap what they sow: the effects of shared values and perceived organizational justice on customers' evaluations of complaint handling," Journal of Marketing, vol. 67, no. 1, pp. 46-62, 2003.

[61] R. Hill, "What sample size is "enough" in internet survey research," Interpersonal Computing and Technology: An electronic journal for the 21st century, vol. 6, no. 3-4, pp. 1-12, 1998.

[62] S. A. Julious, "Sample size of 12 per group rule of thumb for a pilot study," 
Pharmaceutical Statistics: The Journal of Applied Statistics in the Pharmaceutical Industry, vol. 4, no. 4, pp. 287-291, 2005.

[63] J. F. Hair Jr, G. T. M. Hult, C. Ringle, and M. Sarstedt, A primer on partial least squares structural equation modeling (PLS-SEM). Sage publications, 2016. 